\title{
Retrospective observational study on the incidence of oral complications in patients with diabetes mellitus
}

\author{
Studiu observaţional retrospectiv privind incidenţa complicaţiilor orale la \\ pacienţii cu diabet zaharat
}

\author{
Alberta Simona Tinu, Doina Lucia Ghergic, Mirel Stoian, Costin Coman, \\ Raluca-Monica Comăneanu, Adi Lorean \\ Facultatea de Medicină Dentară, Universitatea „Titu Maiorescu“, Bucureşti, România
}

\begin{abstract}
REZUMAT
Obiective. Am efectuat un studiu analitic observaţional retrospectiv cu scopul de a stabili incidenţa complicaţiilor la nivelul cavităţii orale la un lot de pacienţi diagnosticaţi cu diabet zaharat.

Material şi metodă. Am luat în acest sens în studiu un lor de 68 de pacienţi cu diabet zaharat, care s-au adresat unor cabinete de medicină dentară, solicitând tratament de specialitate. Datele extrase din foile de observaţie ale pacienţilor au fost centralizate, clasificate şi prelucrate statistic cu IBM SPSS Statistics 22 şi Microsoft Excel 2010 în funcţie de: sexul pacienţilor, vârsta acestora, tipul de diabet zaharat, perioada scursă de la diagnosticarea diabetului, mediul de provenienţă al pacienţilor, nivelul de instruire al acestora, prezenţa sau absenţa complicaţiilor orale, precum şi în funcţie de valoarea hemoglobinei glicozilate la prezentarea în cabinetul de medicină dentară.

Rezultate. Lotul de pacienţi studiat a avut o medie de vârstă de 56,35 ani, grupa de vârstă 44-54 de ani fiind cel mai bine reprezentată. Lotul studiat a fost compus preponderent din pacienţi de sex feminin, din mediul urban şi cu studii superioare. Jumătate din pacienţii lotului studiat erau diagnosticați cu diabet mai recent de 7 ani, iar valoarea hemoglobinei glicozilate era în medie de 7,309. Incidenţa complicaţiilor diabetului zaharat la nivelul cavității orale la lotul studiat a fost, în ordinea descrescătoare a frecvenței: afecţiuni parodontale, vindecarea întârziată a plăgilor orale, caria dentară, disfuncţiile glandelor salivare, alterarea senzaţiilor gustative, senzaţia de arsură în cavitatea orală, infecţii fungice şi ulceraţii traumatice.

Discuţii. Ambele tipuri de diabet zaharat prezintă complicaţii pe termen lung, direct proporţionale cu durata şi valoarea hiperglicemiei. Cele mai frecvente complicaţii orale ale diabetului descrise în literatura de specialitate s-au regăsit în complicaţiile diagnosticate la pacienţii din lotul studiat.

Concluzii. La lotul studiat, numărul de complicaţii la nivelul cavităţii orale pe care îl prezintă un pacient a fost corelat semnificativ statistic cu valoarea hemoglobinei glicozilate şi cu perioada de timp scursă de la diagnosticarea diabetului zaharat. Nu a existat o corelaţie semnificativă din punct de vedere statistic, între numărul de complicaţii depistate la nivelul cavităţii orale şi nivelul de instruire al pacienţilor.
\end{abstract}

\section{Cuvinte cheie: diabet zaharat, complicaţii orale, studiu retrospectiv, hemoglobină glicozilată}

\begin{abstract}
Objectives. We performed a retrospective observational analytical study to determine the incidence of complications in the oral cavity in a group of patients diagnosed with diabetes mellitus.

Material and method. We have studied 68 diabetic patients, who have been referred to dental practices seeking specialized treatment. Patient data sheets were centralized, categorized, and statistically processed with IBM SPSS Statistics 22 and Microsoft Excel 2010 depending on: sex of patients, age, type of diabetes, time elapsed from diagnosis of diabetes, the environment of origin of the patients, the level of their training, the presence or absence of oral complications and the glycosylated hemoglobin value at presentation in the dental office.

Results. The study group had an average age of 56.35 years, with being the best represented in the age group 44-54. The study group was composed predominantly of female, urban patients and higher-education patients. Half of the patients in the study group were diagnosed with diabetes more than 7 years ago, and the glycosylated hemoglobin value averaged 7.309. The incidence of complications of diabetes in the oral cavity of the studied group was, in decreasing order of frequency: periodontal disease, delayed healing of oral wounds, dental caries, salivary gland dysfunctions, alteration of taste sensations, burning sensation in the oral cavity, fungal infections and traumatic ulcers.
\end{abstract}


Discussions. Both types of diabetes have long-term complications that are directly proportional to the duration and value of hyperglycemia. The most common oral complications of diabetes described in the literature have been found in the complications diagnosed $\mathrm{n}$ the study group patients.

Conclusions. In the studied group, the number of complications in the oral cavity of a patient was statistically correlated with the glycosylated hemoglobin value and with the time elapsed since the diagnosis of diabetes mellitus. There was no statistically significant correlation between the number of complications found in the oral cavity and the level of patient training.

Keywords: diabetes mellitus, oral complications, retrospective study, glycosylated hemoglobin

\section{INTRODUCERE}

Diabetul zaharat este o boală neinfecțioasă produsă de deficitul absolut sau relativ de insulină (1), care, deşi nu este tratată direct de medicul dentist, trebuie să fie cunoscută în amănunt de acesta privind eventualele complicații, din cauza manifestărilor pe care le poate avea în cavitatea orală $(2,3)$.

Deşi, de-a lungul timpului s-a sugerat că anumite manifestări clinice sunt mai frecvente la pacienții cu diabet, rezultatele obținute în diferite studii sunt contradictorii (4). Prezența acestor manifestări clinice orale poate împiedica creşterea calității vieții, care este un deziderat propus (5) şi în cazul pacienților cu diabet. Acest lucru se datorează faptului că modificările produse la nivelul cavității orale pot duce la durere şi disconfort în cursul masticației şi pot înrăutăți afecțiunea de bază, deoarece frecvent modifică, reverberează sau alterează unele procese care afectează anumite organe (6). În schimb, cunoaşterea acestor manifestări poate avertiza medicul dentist cu privire la existenţa unui pacient diabetic încă neidentificat, ajutându-l astfel să pună un diagnostic corect şi să stabilească un plan de tratament corect la nivelul cavității orale, fără teama că s-ar putea confrunta cu complicații neaşteptate (7).

Medicul dentist joacă un rol important în identificarea timpurie a manifestărilor orale ale diabetului, mai ales că mulți pacienți nu cunosc posibilele complicații orale ale diabetului zaharat (8).

\section{MATERIAL ŞI METODĂ}

Am efectuat un studiu analitic observaţional retrospectiv pe un lot de 68 de pacienţi cu diabet zaharat, care s-au adresat pentru tratamente de specialitate unor cabinete de medicină dentară din Bucureşti în perioada decembrie 2015 - noiembrie 2017.

Din fişele de observație ale pacienților respectivi am selectat o serie de date şi antecedente perso- nale, precum şi semne şi simptome ale complicațiilor orale ale diabetului zaharat, protejând identitatea pacienților, cu scopul de a stabili incidența tipurilor de diabet, clasificarea pacienților în funcție de vârsta lor, de nivel lor de instruire, în funcţie de mediul de proveniență, perioada de timp de la diagnosticarea diabetului, valoare hemoglobinei glicozilate la prezentarea în cabinetul de medicină dentară şi incidența complicațiilor la nivelul cavității orale.

Datele selectate din foile de observație au fost prelucrate statistic cu softurile IBM SPSS Statistics 22 şi Microsoft Excel 2010.

\section{REZULTATE OBŢINUTE}

În cadrul studiului am clasificat iniţial pacienții în funcţie de vârsta lor şi de durata de timp de când au fost diagnosticaţi cu diabet zaharat (Graficul 1 şi 2). Astfel, media de vârstă a pacienților din lotul luat în studiu a fost de 56,35 ani, cu un minim de 33 de ani şi un maxim de 85 de ani. $25 \%$ dintre pacienți aveau sub 47 de ani, 50\% din pacienții lotului aveau sub 55 de ani, iar $75 \%$ din pacienții lotului aveau sub 66 de ani.

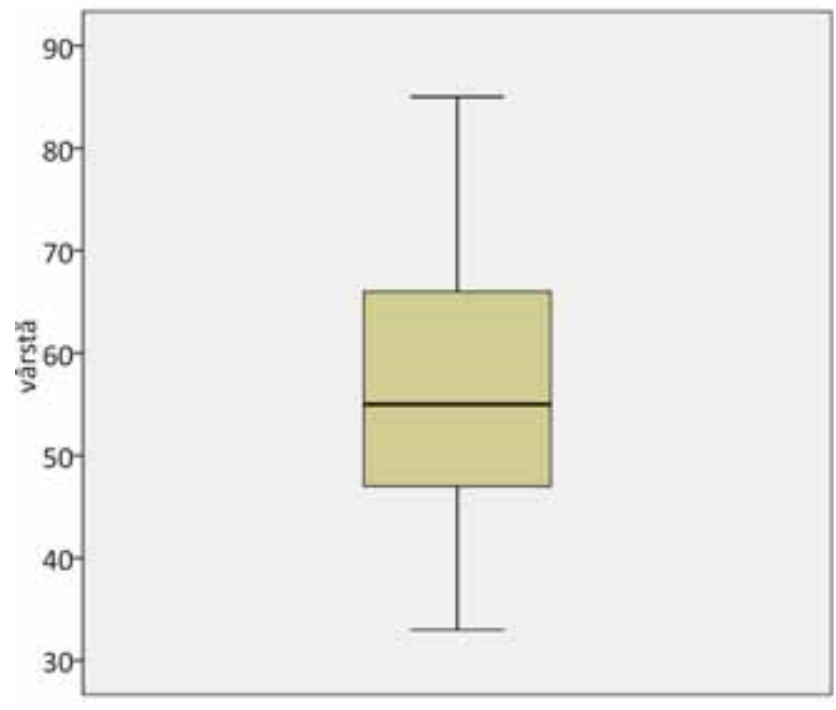

GRAFICUL 1. Clasificarea lotului de studiu pe vârstă 


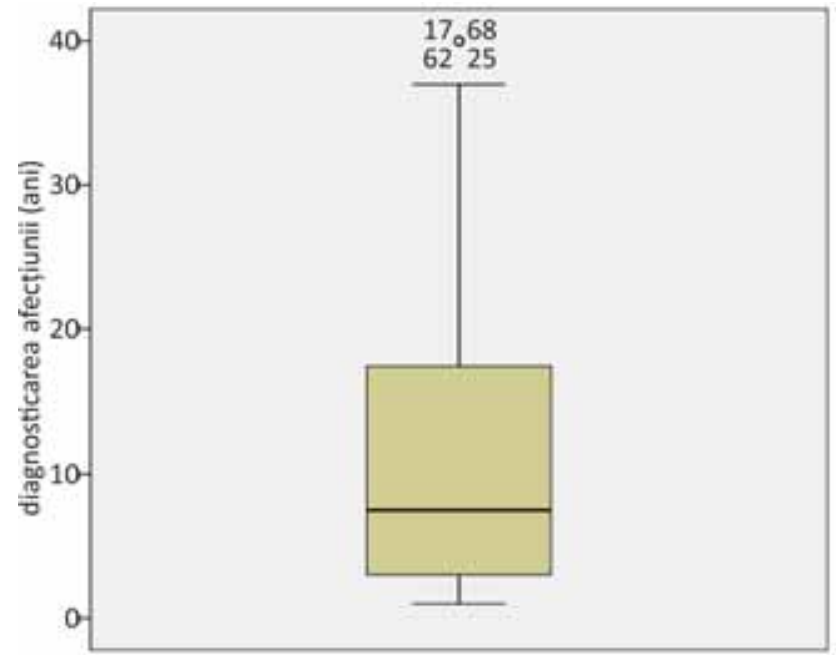

GRAFICUL 2. Clasificarea lotului de studiu în funcție de perioada de timp scursă de la diagnosticarea diabetului zaharat

În ceea ce priveşte durata de timp scursă de la diagnosticarea diabetului până la completarea foilor de observație, aceasta era cuprinsă între 1 an şi 40 ani, cu o medie de 12,49 ani.

$25 \%$ dintre pacienți fuseseră diagnosticați cu diabet de maxim 3 ani, 50\% dintre pacienți erau diagnosticați de maxim 7,5 ani şi $75 \%$ dintre pacienţi fuseseră diagnosticați cu diabet mai devreme de 17,75 ani.

Am mai analizat din punct de vedere statistic lotul în funcție de criterii precum:

- sexul pacienților - pacienții de sex masculin au reprezentat $41,2 \%$ din total

- tipul de diabet zaharat - 73,5\% dintre pacienții lotului fuseseră diagnosticați cu diabet zaharat tip II

- mediul de provenienţă - 60,3\% dintre pacienții lotului proveneau din mediul urban

- nivelul de instruire - 63,2\% din pacienți aveau studii superioare.

Lotul a fost de asemenea clasificat în funcție de incidența complicaţiilor de tipul afecțiunilor parodontale $(63,2 \%)$, disfuncțiilor glandelor salivare $(39,7 \%)$, cariei dentare $(39,7 \%)$, infecțiilor fungice (25\%), ulcerațiilor traumatice $(20,6 \%)$, senzației de arsură în cavitatea orală $(25 \%)$, alterării senzațiilor gustative $(36,8 \%)$, vindecării întârziate a plăgilor orale $(45,6 \%)$.

La lotul studiat, hemoglobina glicozilată a variat între o valoare minimă de $6 \%$ şi un maxim de $11 \%$. Valoarea medie a hemoglobinei glicozilate a fost de 7,309\% (Graficul 3).

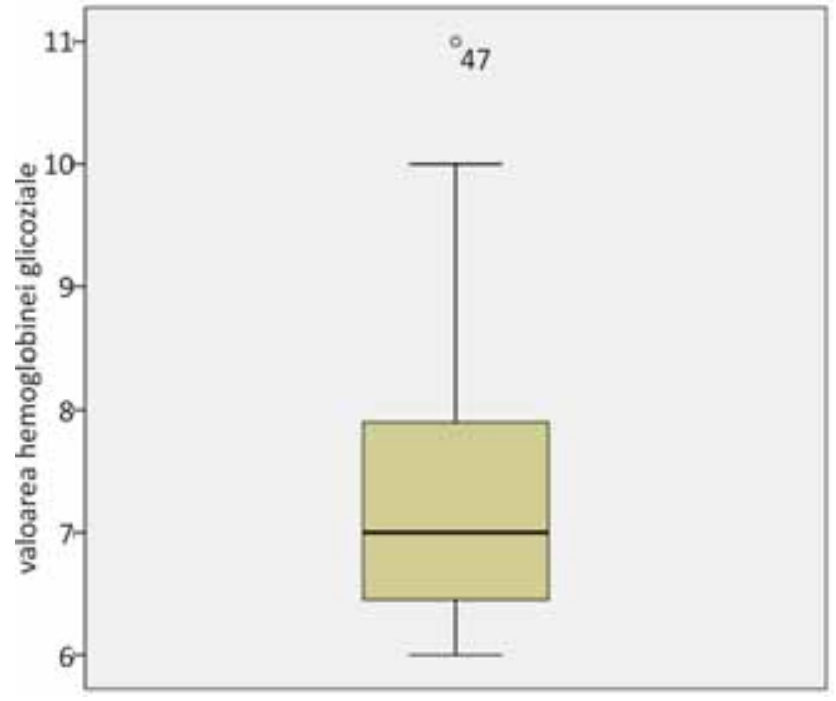

GRAFICUL 3. Clasificarea lotului în funcție de valoarea hemoglobinei glicozilate

$25 \%$ dintre valorile înregistrate au fost sub $6,425,50 \%$ dintre valorile înregistrate s-au situat sub pragul de 7 , iar $75 \%$ din valorile înregistrate au fost sub pragul de 7,9 .

17 pacienți (25\% din lotul studiat) prezentau o valoare a hemoglobinei glicozilate mai mică sau egală cu 6,4 , ceea ce indică un foarte bun control glicemic.

Lotul a fost clasificat şi din punct de vedere al numărului de complicații depistate, pe sexe (Graficul 4).

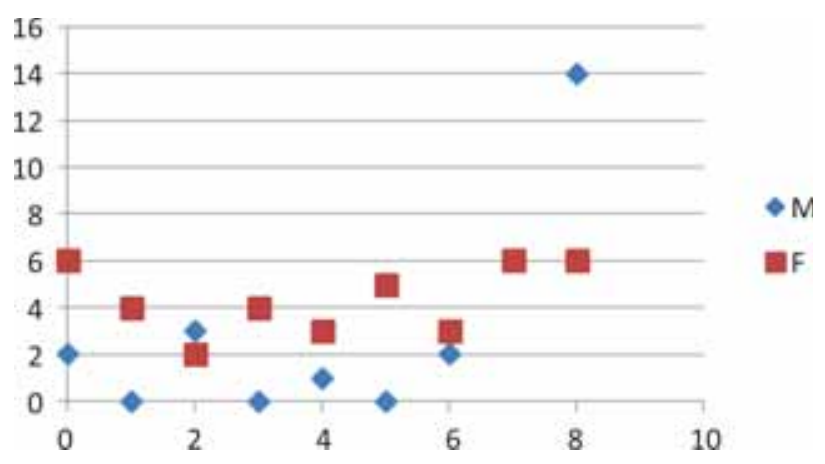

GRAFICUL 4. Clasificarea lotului studiat în funcție de numărul de complicații, pe sexe

Pentru lotul studiat, 14 pacienți de sex masculin au avut câte 8 complicații la nivelul cavității orale, față de 6 pacienți pentru sexul feminin.

În schimb, 39 de paciente au avut în general complicații orale (indiferent de numărul propriuzis de complicații pe care îl prezenta fiecare pacientă în parte), față de 28 de pacienți de sex masculin.

La lotul studiat am constatat prezența unei corelații semnificative statistic între valoarea hemoglo- 
binei glicozilate şi numărul de complicații la nivelul cavității orale pe care îl prezintă un pacient, existând între acestea o dependenţă direct proporțională, cu un coeficient de corelație $r=0,7011$.

De asemenea, la lotul studiat am observant o dependență direct proporțională, semnificativă statistic, cu un coeficient $r=0,7060$, între numărul de complicații depistat la nivelul cavității orale la un pacient şi perioada de timp scursă de la diagnosticarea diabetului zaharat.

Pentru lotul studiat nu am depistat o corelație semnificativă statistic între numărul de complicații depistate la nivelul cavității orale şi nivelul de instruire al pacienților, coeficientul $r$ fiind 0,0557 .

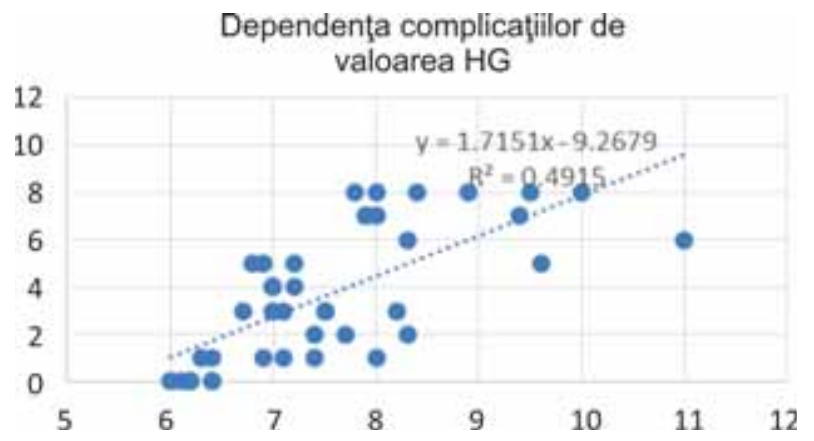

GRAFICUL 5. Dependența numărului de complicații la nivelul cavității orale de valoarea hemoglobinei glicozilate a pacienților

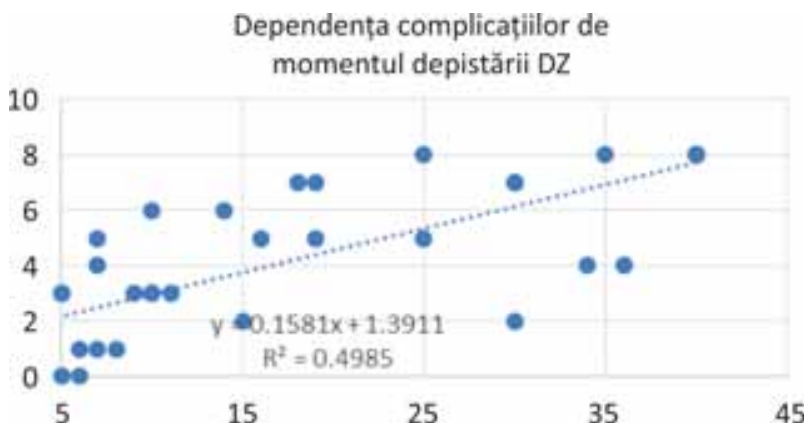

GRAFICUL 6. Dependența numărului de complicații depistate la nivelul cavității orale de momentul diagnosticării diabetului zaharat

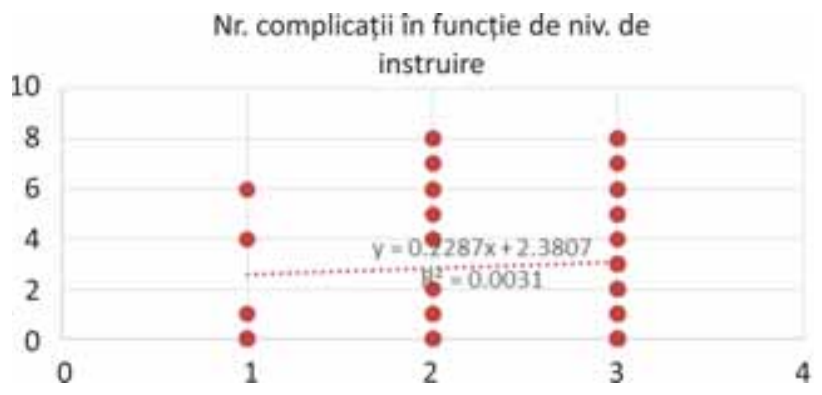

GRAFICUL 7. Dependența numărului de complicații depistate la nivelul cavității orale de nivelul de instruire al pacienților

\section{DISCUŢII}

Atât diabetul zaharat de tip I, cât şi diabetul zaharat de tip II prezintă numeroase complicații pe termen lung (9). Studiile epidemiologice arată faptul că gravitatea complicațiilor diabetului este în general proporțională cu gradul şi durata hiperglicemiei (10).

Manifestările orale ale diabetului zaharat cu prevalență crescută $(11,12)$ descrise în literatura de specialitate sunt: gura uscată, cariile dentare, afecțiuni parodontale, candidoză orală, sindromul de arsură orală, afectarea gustului, lichen plan oral, limba geografică sau fisurată, vindecarea întârziată a plăgilor orale, creşterea incidenţei infecțiilor, disfuncții salivare, alterarea gustului şi alte manifestări neurosenzitive, hipertrofie parotidiană benignă (13).

Eficacitatea salivei în neutralizarea mediului acid oral este foarte redusă la pacienţii cu diabet (14), iar procesele de demineralizare/remineralizare din cavitatea orală sunt puternic influențate de factorul salivar (15).

Pacienții diabetici sunt mai susceptibili la procesele infecțioase, mai ales când acestea sunt produse de bacterii anaerobe ca urmare a reducerii difuziunii oxigenului prin pereții capilarelor (16).

Diabetul zaharat creşte riscul incidenței afecțiunilor parodontale, dar impactul afecțiunilor parodontale asupra controlului glicemiei şi mecanismul prin care se produce nu este încă elucidat complet (17). Hiperglicemia este un stimul al resorbției osoase, ce inhibă diferențierea osteoblaştilor şi reduce capacitatea refacerii osoase (18).

Alterarea senzațiilor gustative urmează un tipar ereditar, dar poate fi influențată de apariţia neuropatiei (9). Alterarea senzațiilor gustative a fost asociată cu prezența diabetului (19).

Sindromul de arsură la nivelul cavității orale este caracterizat de senzaţia de arsură la nivelul mucoasei orale în absența semnelor clinice (9). Sindromul este mai comun la femei cu vârsta cuprinsă între 50 şi 60 de ani (20) conform literaturii. Sindromul de arsură la nivelul cavităţii orale este frecvent întâlnit la pacienții cu diabet, dar nu a fost identificată o relație clară între diabetul zaharat şi acest sindrom (21).

\section{CONCLUZII}

Lotul de pacienți studiat a fost alcătuit preponderent din pacienți de sex feminin, cu diabet zaha- 
rat de tip II, proveniți din mediul urban şi cu studii superioare.

$50 \%$ dintre pacienții lotului fuseseră diagnosticați cu diabet zaharat mai recent de 7 ani.

În ordinea descrescătoare a frecvenței, am depistat la lotul studiat următoarele complicații: afecțiuni parodontale $(63,2 \%)$, vindecarea întârziată a plăgilor orale $(45,6 \%)$, caria dentară $(39,7 \%)$, disfuncțiile glandelor salivare $(39,7 \%)$, alterarea senzațiilor gustative $(36,8 \%)$, senzaţia de arsură în cavitatea orală $(25 \%)$, infecții fungice $(25 \%)$ şi ulcerații traumatice $(20,6 \%)$.

La lotul studiat, numărul de complicaţii la nivelul cavității orale pe care îl prezenta un pacient a fost corelat semnificativ statistic cu valoarea hemo- globinei glicozilate şi cu perioada de timp scursă de la diagnosticarea diabetului zaharat.

La lotul studiat nu a existat o corelaţie semnificativă din punct de vedere statistic, între numărul de complicații depistate la nivelul cavității orale şi nivelul de instruire al pacienților.

\section{Acknowledgements}

Acest studiu, fiind unul retrospectiv, nu a necesitat consimţământul scris al pacienților implicaţi. Autorii nu au declarat niciun conflict de interese privind acest studiu. Toți autori au citit, au aprobat şi au avut o contribuţie egală la publicarea acestui material.

Financial support: none declared

\section{BIBLIOGRAFIE}

1. Cardozo E., Pardi G. Consideraciones a tomar en cuenta en el manejo odontológico del paciente con diabetes mellitus. Acta Odontol Venez. 2003; 41 (1): 63-66.

2. Kaur S., Kaur K., Rai S. et al. Oral health management considerations in patients with diabetes mellitus. Arch Med Health Sci. 2015; 3: 72-79.

3. Baloch G.H., Dall A.Q., Hayat A.S. et al. Type 2 diabetes mellitus; Dental caries în patients. Professional Med J. 2013; 20: 237-243.

4. Page R.C., Beck J.D. Risk assessment for periodontal diseases. Int Dent J. 1997; 47 (2): 61-87.

5. Mazzini Torres F., Mazzini W.U., Moreira Campuzano T. Predisposing factors affecting oral health in diabetes mellitus patients, Revista Odontológica Mexicana, Vol. 21, No. 2 April-June 2017, pp e101-e106.

6. Carrizales M. Estado actual de la lucha antidiabética en Venezuela. Libro de resúmenes del III Congreso Venezolano de Endocrinología y Metabolismo. Caracas: 1991, pp. 1-20.

7. Espeso-Nápoles N., Mulet-García M., Gómez-Mariño M. et. al. Enfermedad periodontal en la tercera edad. AMC, 2006; 10 (1): 42-52.

8. Panchbhai A. Oral Considerations in Diabetes Mellitus, chapter in Recent Advances in Diabetes Treatment, First Published December 16, 2015.

9. Mauri-Obradors E., Estrugo-Devesa A., Jané-Salas E. et al. Oral manifestations of Diabetes Mellitus. A systematic review. Med Oral Patol Oral Cir Bucal. 2017 Sep 1; 22 (5):e586-94.

10. Tandon N., Ali M.K., Narayan K.M.V. Pharmacologic prevention of microvascular and macrovascular complications in diabetes mellitus: implications of the results of recent clinical trials in type 2 diabetes. Am J Cardiovasc Drugs. 2012; 12:7-22.

11. Busato I.M.S., Ignácio S.A., Brancher J.A. et al. Impact of clinical status and salivary conditions on xerostomia and oral health-related quality of life of adolescents with type 1 diabetes mellitus. Community Dent Oral Epidemiol. 2012; 40:62-9.
12. Ivanovski K., Naumovski V., Kostadinova M. et al. Xerostomia and salivary levels of glucose and urea in patients with diabetes. Pril / Makedon Akad na Nauk i Umet Oddelenie za biološki i Med Nauk = Contrib / Maced Acad Sci Arts, Sect Biol Med Sci. 2012; 33:219-29.

13. Albert D.A., Ward A., Allweiss P. et al. Diabetes and oral disease: Implications for health professionals. Ann N Y Acad Sci. 2012; 1255:1-15.

14. Stetiu A.A., Dancila A., Mitariu M. et al. The influence of the chemical composition of the saliva, buffer capacity and the salivary $\mathrm{pH}$ on children with diabetes compared to non diabetics, Revista de Chimie, vol. 67(10), 2016, pag. 1966-1969, ISSN: 0034-7752.

15. Boitor G.C., Cormos G., Stetiu A. et al. Associating Certain Salivary Parameters with Oral Health for a Group of Patients with Type II Diabetes Mellitus, Revista de Chimie, vol. 67(11), 2016, pag. 2314-2317, ISSN: 0034-7752.

16. Segura-Egea J.J., Castellanos-CoHealthy L., Machuca G. et al. Diabetes mellitus, periapical inflammation and endodontic treatment outcome. Med Oral Patol Oral Cir Bucal. 2012; 17:356-61.

17. Mauri-Obradors E., Jané-Salas E., Sabater-Recolons M.D.M. et al. Effect of nonsurgical periodontal treatment on glycosylated hemoglobin in diabetic patients: a systematic review. Odontology. 2014; 103:301-13.

18. Lima S.M.F., Grisi D.C., Kogawa E.M. et al. Diabetes mellitus and inflammatory pulpal and periapical disease: A review. Int Endod J. 2013; 46:700-9.

19. Leite R.S., Marlow N.M., Fernandes J.K. Oral health and type 2 diabetes. Am J Med Sci. Elsevier Masson SAS; 2013; 345:271-3.

20. Spanemberg J.C., Rodríguez de Rivera Campillo E., Salas E.J. et al. Burning Mouth Syndrome: update. Oral Health Dent Manag. 2014; 13:418-24.

21. Vesterinen M., Ruokonen H., Furuholm J. et al. Clinical questionnaire study of oral health care and symptoms in diabetic vs. non-diabetic predialysis chronic kidney disease patients. Clin Oral Investig. 2012; 16:559-63 